\title{
Serum Soluble TWEAK Concentration is Decreased in Patients with Hepatocellular Cancer and Low Blood Levels of sTWEAK are Associated with Poor Survival
}

\author{
Mehmet ASIL, Ramazan DERTLI \\ Necmettin Erbakan University, Meram Faculty of Medicine, Department of Gastroenterology, Konya, TURKEY
}

\begin{abstract}
Tumor necrosis factor-like weak inducer of apoptosis (TWEAK) is a member of the tumor necrosis factor superfamily and has been implicated in the pathogenesis of several cancers. This study was conducted to investigate serum sTWEAK levels and its relation with prognosis in patients with hepatocellular carcinoma (HCC). Twenty-eight cirrhotic patients with HCC, 28 patients with cirrhosis and 30 healthy subjects were included in the study. Serum sTWEAK concentrations were measured by using commercially available enzyme-linked immune sorbent assay kits. Mean serum STWEAK concentrations in HCC, cirrhosis and healthy control groups were $174.0 \pm 69.9 \mathrm{pg} / \mathrm{ml}, 221.4 \pm 61.2 \mathrm{pg} / \mathrm{ml}$ and $288.0 \pm 68.4 \mathrm{pg} / \mathrm{ml}$ respectively and the difference between the groups was statistically significant $(p<0.001)$. Mean sTWEAK concentration in the HCC group was significantly lower than both cirrhosis group $(p=0.009)$ and healty controls $(p<0.001)$. In the ROC curve analysis, AUC for serum TWEAK concentration to predict one-year mortality in HCC patients was 0.836 (95\% Cl: $0.684-0.987$ ) and for the specified cut-off value of $148.1 \mathrm{pg} / \mathrm{ml}$, sensitivity and specificity were $66.7 \%$ and $92.3 \%$ respectively. Kaplan-Meier survival estimates showed that, survival rate was significantly lower in patients with serum sTWEAK $<148.1 \mathrm{pg} / \mathrm{ml}$ (log-rank test, chi-square= 11.75, $p=0.001)$. Serum sTWEAK concentration was identified as an independent predictor of mortality in Cox regression analysis (Hazard ratio= 4.325, \%95 Cl: 1.080-17.326, $p=0.025$ ). Serum sTWEAK concentration is decreased in HCC patients. Lower serum STWEAK concentrations at the time of diagnosis are associated with poor prognosis and higher one-year mortality rates in HCC patients.
\end{abstract}

Keywords: Tumor necrosis factor-like weak inducer of apoptosis, Hepatocellular cancer, Survival rate, Mortality

ÖZET

Serum Solubl TWEAK Konsantrasyonu Hepatoselüler Kanser Hastalarında Azalmıştır ve Düşük Kan sTWEAK Düzeyleri Kötü Sağkalımla İlişkilidir

Tumor necrosis factor-like weak inducer of apoptosis (TWEAK) tümör nekrozis factor ailesinin bir üyesidir ve birçok kanserin patogenezinde rol oynadığı öne sürülmüştür. Bu çalışmada hepatoselüler kanser (HCC) hastalarında serum sTWEAK düzeylerinin araştıııması amaçlanmıştır. Yirmi sekiz HCC hastası, 28 siroz hastası ve 30 sağlıklı kontrol çalışmaya dahil edilerek serum sTWEAK konsantrasyonları ELISA yöntemiyle hazır kitler kullanılarak çalışılmıştır. HCC, siroz ve sağıklı kontrol gruplarında ortalama serum

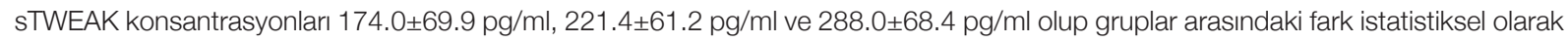
anlamlıydı $(p<0.001)$. HCC grubundaki ortalama sTWEAK konsantrasyonunun gerek siroz $(p=0.009)$ gerek de sağlıklı kontrol $(p<$ 0.001) gruplarından daha düşük olduğu görüldü. ROC analizinde, sTWEAK için 1 yıllık mortaliteyi öngörme açısından eğri altında kalan alan 0.836 (\%95Cl: 0,684-0,987) ve belirlenen148,1 pg/ml eşik değeri için duyarllık ve özgüllük \%66.7 ve \%92.3 olarak bulundu. Kaplan-Meier sağkalım analizi ile serum sTWEAK konsantrasyonu < 148,1pg/ml olan hastalarda 1 yllık sağkalım hızının anlamlı olarak daha düşük olduğu görüldü (log-rank testi, ki-kare=11.75, p= 0.001). Cox regresyon analizinde de serum sTWEAK konsantrasyonunun mortaliteyi öngören bağımsız bir risk faktörü olduğu görüldü (Hazard oranı= 4.325, \%95 Cl: 1.080-17.326, p= 0.025). HCC hastalarında serum sTWEAK konsantrasyonu azalmıştır. Düşük serum sTWEAK düzeyleri, HCC hastalarında kötü prognoz ve yüksek bir yıllık mortalite oranlarıyla ilişkilidir.

Anahtar Kelimeler: Tümör nekroze edici faktör benzeri zayıf apoptoz indükleyicisi, Hepatoselüler kanser, Sağkalım hızı, Ölüm oranı 


\section{INTRODUCTION}

Hepatocellular carcinoma (HCC) is the most commonly encountered liver cancer and it is one of the most common causes of cancer deaths worldwide. ${ }^{1}$ Hepatitis B virus (HBV), Hepatitis C virus, fatty liver disease, chronic alcohol consumption, metabolic diseases and liver cirrhosis are well known risk factors for the development of hepatocellular carcinoma. As most other cancers, the pathogenesis of HCC is multifactorial and complex, involving interactions of genetic factors, oncogenes and tumour suppressor genes with resultant alterations in different signaling cascades related to cell survival and proliferation. ${ }^{2}$ Currently, there is no optimal treatment modality for HCC and better understanding of the factors contributing to the pathogenesis of the disease would pave way to development of novel treatment strategies.

Tumor necrosis factor-like weak inducer of apoptosis (TWEAK) is a type II transmembrane protein. It is a member of the tumor necrosis factor (TNF) superfamily. Extracellular domain of membrane bound TWEAK is cleaved by proteases releasing a soluble biologically active molecule acting as a cytokine (soluble TWEAK, sTWEAK). ${ }^{3}$ sTWEAK binds to its receptor known as fibroblast growth factor-inducible 14 (Fn14) and TWEAK/ Fn14 interaction has been shown to affect several cellular responses such as proliferation, differentiation, apoptosis, angiogenesis and inflammation. ${ }^{4}$ TWEAK/Fn14 axis is of particular importance in tissue repair, fibrogenesis and remodeling and it has been show to contribute to the pathogenesis of many diseases including several cancers. ${ }^{5-8} \mathrm{Re}-$ cently TWEAK/Fn14-cancer interaction has drawn significant attention and inhibition of this axis has even been investigated as a therapeutic anticancer strategy in some studies. ${ }^{4,9}$ TWEAK/Fn14 axis has also been implicated in the pathogenesis of chronic liver diseases of various etiologies and HCC. ${ }^{10-12}$ To the best of our knowledge, there is no study in the literature investigating serum sTWEAK levels in HCC patients; therefore current was conducted to evaluate serum sTWEAK levels in patients with HCC and cirrhosis associated with chronic HBV infection.

\section{PATIENTS AND METHODS}

This study was a prospective observational cohort study. Twenty-eight HBV (+) cirrhotic patients with HCC, $28 \mathrm{HBV}(+)$ patients with cirrhosis and 30 healthy subjects were included in the study, the latter two groups served as controls. This study has been performed in accordance with the ethical standards of Declaration of Helsinki. Ethical approval was obtained from Necmettin Erbakan University, Meram Faculty of Medicine. Written informed consents were taken from all participants. HCC group consisted of patients with chronic HBV infection whom HCC was diagnosed either with biopsy and histological examination of tissue specimens or on the basis of typical radiological findings in dynamic postcontrast computerized tomography or magnetic resonance imaging studies. Typical radiological criteria were defined as follows; arterial hypervascularity showing itself as increased contrast enhancement of the lesion in the hepatic arterial phase of the imaging relative to the background liver followed by washout of the lesion in the portal and hepatic phases. All of the patients in the HCC group were newly diagnosed, treatment naive patients. Patients with a prior history of HCC treatment were excluded from the study even if they had an active lesion on dynamic imaging. Barcelona Clinic Liver Cancer (BCLC) and Okuda staging systems and Milan criteria were used for staging HCC patients. ${ }^{13-15}$

Cirrhosis group on the other hand consisted of patients with chronic HBV infection whom cirrhosis was diagnosed with typical clinical, laboratory and radiological findings. Patients with acute complications of cirrhosis such as hepatic encephalopathy, spontaneous bacterial peritonitis, esophageal or gastric variceal bleeding and hepatorenal syndrome were not included in the cirrhotic group since such complications may affect serum sTWEAK concentrations. HCC surveillance was performed in the cirrhotic group with transabdominal USG and serum alpha-feto protein levels and patients with any suspicious lesions were also excluded from the study. All of the patients in both HCC and cirrhosis groups were hepatitis B surface antigen (HBs $\mathrm{Ag}$ ) positive for at least 6 months. Anti-HCV antibody, anti nuclear antibody, anti smooth muscle antibody, anti liver-kidney microsomal antibody, 
serum copper and ceruloplasmin levels and serum transferring saturation were obtained from all patients in the HCC and cirrhosis groups to exclude any other cause of chronic liver disease. Healthy control group consisted of 30 healthy people with normal liver enzymes and negative serological tests for hepatitis B and C (Hepatitis B surface antigen, Hepatitis B core antigen, anti-HCV antibody). Patients with known malignancies, chronic renal diseases, autoimmune diseases, or any ongoing active infections were also excluded from the study. Serum samples from the patients and healthy controls were obtained early in the morning after at least 8 hours of fasting. Complete blood counts and serum chemistries were analyzed in our hospital's laboratory using standard automated analyzers. Serum samples for sTWEAK were separated by centrifugation at $4000 \mathrm{rpm} / \mathrm{min}$ for 5 minutes at $4^{\circ} \mathrm{C}$. Samples were immediately transferred to freezer and stored at $-80^{\circ} \mathrm{C}$ until final analyzes. Measurements of sTWEAK concentrations were done on the same day, using commercially available enzyme-linked immune sorbent assay kits (eBioscience, Human TWEAK Instant Elisa, Cat no: BMS2006INST). The results were given in $\mathrm{pg} / \mathrm{ml}$.

Statistical analyzes were carried out using computer software "The Statistical Package for the Social Sciences 19.0 (SPSS Armonk, NY: IBM Corp.)" for Windows. Continuous variables were expressed as mean \pm standard deviation and categorical data were given as frequencies and percentages (n, \%). Continuous variables were tested for normal distribution using one sample Kolmogorov-Smirnov test. When the tested parameter was normally distributed, one way Anova test (comparison of more than two groups) and student's t test (binary comparisons) were used to test the significance of difference between the groups. For non-normally distributed parameters, Mann-Whitney U test was used to search for the significance of difference between two groups and and Kruskall-Wallis test for more than two groups. Categorical variables were compared using chi-squared test. Receiver operating characteristic (ROC) curves were obtained for sTWEAK to test the ability of sTWEAK concentration to predict one-year mortality in HCC patients. When a significant cut-off value was observed, sensitivity, specificity, positive and nega- tive predictive values were calculated. Survival curves were plotted using Kaplan-Meier methods and the log-rank test was used to compare curves. Cox regression analysis was used to identify the independent predictors of mortality. Statistical significance for all analyses were defined as $\mathrm{p}<0.05$.

\section{RESULTS}

Demographical characteristics and laboratory data of the groups were summarized in Table 1. Mean age of the study group was $57.7 \pm 9.1$ years. The groups were similar in terms of age and gender distribution ( $\mathrm{p}=0.310$ and $\mathrm{p}=0.089$ respectively).

Mean serum sTWEAK concentrations in HCC, cirrhosis and healthy controls were $174.0 \pm 69.9 \mathrm{pg} / \mathrm{ml}$, $221.4 \pm 61.2 \mathrm{pg} / \mathrm{ml}$ and $288.0 \pm 68.4 \mathrm{pg} / \mathrm{ml}$ respectively and there was a statistically significant difference between the groups $(\mathrm{p}<0.001)$. Intergroup comparisons showed that HCC group had significantly lower serum sTWEAK concentrations than both cirrhosis group $(\mathrm{p}=0.009)$ and healthy controls $(\mathrm{p}<0.001)$. Cirrhotic group also had significantly lower mean serum sTWEAK concentration than healthy controls $(\mathrm{p}<0.001)$.

Mean Child Pugh scores in the HCC and cirrhosis groups were $8.0 \pm 2.5$ and $7.4 \pm 2.2$ respectively and the difference between the groups was not statistically significant $(\mathrm{p}=0.371)$. There were 12 patients (42.9\%) with Child-Pugh class A, 9 patients $(32.1 \%)$ with Child-Pugh class B and 7 patients (25.0\%) with Child-Pugh class $\mathrm{C}$ in the cirrhosis group. HCC group, on the other hand, consisted of 10(35.7\%) Child-Pugh class A, 10 (35.7\%) ChildPugh class B and 8 (28.6\%) Child-Pugh class C (\%25) patients. The distribution of the patients according to Child-Pugh stages were also found to be similar in the cirrhosis and HCC groups $(\mathrm{p}=0.86)$. Mean MELD score was $11.7 \pm 4.0$ in the HCC group and $11.9 \pm 4.3$ in the cirrhosis group and the difference between the groups was again statistically insignificant $(\mathrm{p}=0.91)$.

Patients in the HCC group were staged according to BCLC and Okuda classification systems and Milan criteria as previously noted. Mean serum sTWEAK concentrations of the patients in the HCC group according to BCLC and Okuda stages 
Table 1. Clinical and demographical characteristics and laboratory data of the groups

\begin{tabular}{|c|c|c|c|c|}
\hline & $\begin{array}{l}\text { HCC } \\
(n=28)\end{array}$ & $\begin{array}{l}\text { Cirrhosis } \\
(n=28)\end{array}$ & $\begin{array}{l}\text { Control group } \\
(n=30)\end{array}$ & $\mathbf{p}$ \\
\hline Age (years) & $59.7 \pm 10.1$ & $57.7 \pm 9.2$ & $56.0 \pm 7.9$ & 0.310 \\
\hline Male (n, \%) / female (n, \%) & $24(85.7) / 4(14.3)$ & 19(67.9)/9(32.1) & $18(60) / 12(40)$ & 0.089 \\
\hline Glucose (mg/dl) & $116.9 \pm 53.1 \mathrm{a}, \mathrm{b}$ & $138.7 \pm 61.4 \mathrm{~b}$ & $100.4 \pm 14.3 \mathrm{a}$ & 0.012 \\
\hline Creatinine (mg/dl) & $0.8 \pm 0.2$ & $0.9 \pm 0.4$ & $0.8 \pm 0.1$ & 0.468 \\
\hline $\operatorname{ALT}(\mathrm{U} / \mathrm{L})$ & $61.3 \pm 48.5 \mathrm{a}$ & $44.3 \pm 38.7 \mathrm{a}$ & $19.8 \pm 8.8 b$ & $<0.001$ \\
\hline AST (U/L) & $79.6 \pm 48.0 \mathrm{a}$ & $61.9 \pm 52.7 \mathrm{a}$ & $21.2 \pm 6.3 b$ & $<0.001$ \\
\hline GGT (U/L) & $123.5 \pm 84.6 \mathrm{a}$ & $80.1 \pm 74.0 \mathrm{a}$ & $26.3 \pm 15.0 \mathrm{~b}$ & $<0.001$ \\
\hline ALP (U/L) & $156.8 \pm 92.9 \mathrm{a}$ & $105.1 \pm 45.2 \mathrm{~b}$ & $68.3 \pm 14.0 \mathrm{c}$ & $<0.001$ \\
\hline Total bilirubin (mg/dl) & $2.0 \pm 1.9 \mathrm{a}$ & $2.3 \pm 2.7 \mathrm{a}$ & $0.7 \pm 0.4 b$ & 0.012 \\
\hline Direct bilirubin (mg/dl) & $0.9 \pm 0.9 a$ & $1.0 \pm 1.7 \mathrm{a}$ & $0.2 \pm 0.1 \mathrm{~b}$ & 0.035 \\
\hline Albumin (g/dl) & $3.1 \pm 0.7 \mathrm{a}$ & $3.5 \pm 0.6 b$ & $4.3 \pm 0.6 \mathrm{c}$ & $<0.001$ \\
\hline Hemoglobin (g/dl) & $12.2 \pm 2.0 \mathrm{a}$ & $12.8 \pm 2.4 \mathrm{a}$ & $14.7 \pm 1.4 b$ & $<0.001$ \\
\hline Leukocyte (1000/mm3) & $6.6 \pm 2.3 \mathrm{a}$ & $5.1 \pm 1.9 b$ & $7.3 \pm 1.3 \mathrm{a}$ & $<0.001$ \\
\hline Platelet (1000/mm3) & $148.6 \pm 71.7 \mathrm{a}$ & $95.2 \pm 47.5 b$ & $261.3 \pm 47.5 \mathrm{c}$ & $<0.001$ \\
\hline AFP (U/ml) & $104.2 \pm 214.0 \mathrm{a}$ & $5.4 \pm 3.6 b$ & - & 0.027 \\
\hline MELD score & $11.7 \pm 4.0$ & $11.9 \pm 4.3$ & & 0.911 \\
\hline Child-Pugh score & $8.0 \pm 2.5$ & $7.4 \pm 2.2$ & - & 0.371 \\
\hline STWEAK & $174.0 \pm 69.9 \mathrm{a}$ & $221.4 \pm 61.2 \mathrm{~b}$ & $288.0 \pm 68.4 \mathrm{c}$ & $<0.001$ \\
\hline
\end{tabular}

and Milan criteria are summarized in Table 2. Although there was a progressive decrease in mean serum sTWEAK concentration in parallel to advanced BCLC stage, it did not reach a statistically significant level $(p=0.075)$. The differences in mean serum sTWEAK concentrations of patients with Okuda stages 1,2 and 3 were not also statistically significant $(\mathrm{p}=0.686)$. But the situation was different for Milan criteria; thirteen (46.4\%) patients in the HCC group were found to fulfill Milan criteria at the time of initial diagnosis and mean serum STWEAK concentration in this group was $201.1 \pm 56.8 \mathrm{pg} / \mathrm{ml}$. On the other hand mean serum sTWEAK concentration of the $15(53.6 \%)$ patients who were beyond the Milan criteria at the time of initial diagnosis was $150.5 \pm 73.4$ and it was significantly lower than patients fulfilling the Milan criteria $(\mathrm{p}=0.025)$.

Mean follow up time in the HCC group was 7.8 \pm 4.4 months. Fifteen (53.6\%) patients in the HCC group died during one year of follow-up period and the median survival was 4 months (range: 1-10 months). There were 13 (46.4\%) HCC patients fulfilling the Milan criteria at the time of initial diagnosis and only $2(15.4 \%)$ of them died during one year of follow up period. On the other hand, among the $15(53.6 \%)$ patients beyond the Milan criteria, $13(86.7 \%)$ of them died within one year and the difference between the groups was statistically significant $(\mathrm{p}<0.001)$. Kaplan-Meier survival estimates were calculated for the two groups of patients who were within or beyond the Milan criteria at the time of initial diagnosis and log-rank test was used to compare the curves. Overall survival was defined as the time from initial diagnosis of HCC to death. Analyzes showed that patients who met Milan criteria at the time of initial diagnosis had longer survival rates than those patients who did not (log-rank test, chi-square $=17.522, \mathrm{p}<$ 0.001). Kaplan-Meier curves are given in Figure 1. BCLC and Okuda stages, total tumor diameter and mean serum sTWEAK concentrations were also 


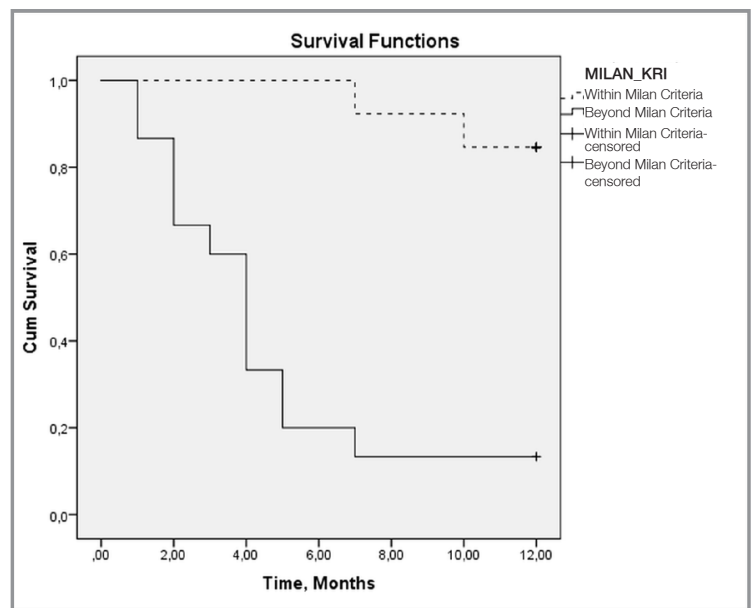

Figure 1. Kaplan-Meier curves for patients who met or who were beyond the Milan criteria at the time of initial diagnosis.

significantly different between surviving and nonsurviving HCC patients. Findings are summarized in Table 3. Mean serum sTWEAK concentration of the deceased group was $139.1 \pm 59.8 \mathrm{pg} / \mathrm{ml}$ and it was significantly lower than the survivor group, which had a mean serum STWEAK concentration of $214.2 \pm 59.5 \mathrm{pg} / \mathrm{ml}(\mathrm{p}=0.002)$.

ROC curve analysis was done to determine the ability of serum sTWEAK concentration to predict one-year mortality in HCC patients (Figure 2). AUC was 0.836 (95\% CI: 0.684-0.987) and for the specified cut-off value of $148.1 \mathrm{pg} / \mathrm{ml}$, sensi-

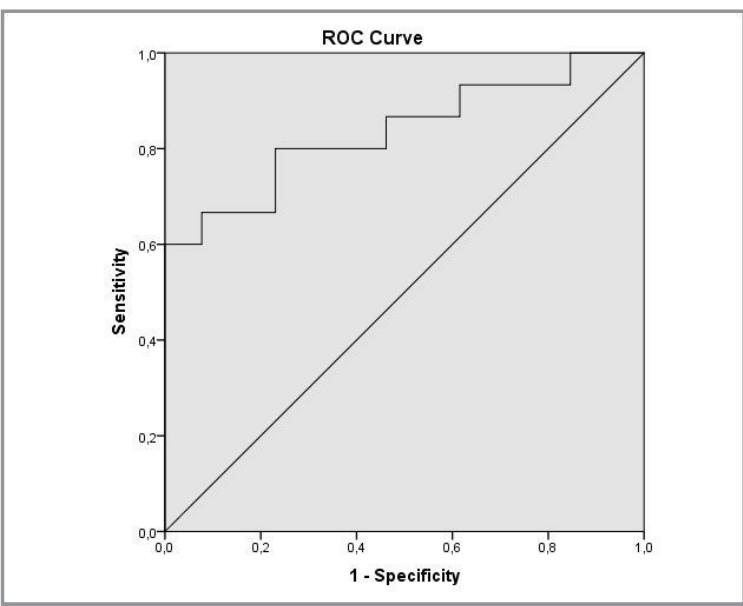

Figure 2. ROC curve for STWEAK to predict one-year mortality in HCC patients.

tivity and specificity were $66.7 \%$ and $92.3 \%$ and calculated positive and negative predictive values were $90.9 \%$ and $70.6 \%$ respectively. Patients in the HCC group were divided into two groups according to the cut-off value determined from the ROC analyzes; group 1 consisted of 11 (39.3\%) patients with sTWEAK $<148.1 \mathrm{pg} / \mathrm{ml}$ and group 2 consisted of $17(60.7 \%)$ patients with sTWEAK $\geq 148.1 \mathrm{pg} /$ $\mathrm{ml}$. Ten (90.9\%) patients in group 1 and $5(29.4 \%)$ patients in group 2 died during one year follow-up period. Kaplan-Meier survival estimates were calculated for group 1 and group 2 patients and sur-

Table 2. Clinical and laboratory data of survivor and non-survivor patients

\begin{tabular}{|c|c|c|c|}
\hline & HCC Survivors $(n=13)$ & HCC Non-Survivors $(n=15)$ & $\mathbf{p}$ \\
\hline Age & $59.0 \pm 12.2$ & $60.3 \pm 8.3$ & 0.892 \\
\hline Within Milan Criteria (n, \%) & $11(84.6)$ & $2(15.4)$ & $<0.001$ \\
\hline Child-Pugh stage (A/B/C) & $7 / 2 / 4$ & $3 / 8 / 4$ & 0.079 \\
\hline MELD score & $11.7 \pm 3.8$ & $11.8 \pm 4.2$ & 0.781 \\
\hline BCLC stage (O/A/B/C/D) & $7 / 5 / 1 / 0 / 0$ & $0 / 2 / 3 / 8 / 2$ & 0.001 \\
\hline Okuda stage (A/B/C) & $8 / 5 / 0$ & $1 / 10 / 4$ & 0.004 \\
\hline AFP (U/ml) & $39.6 \pm 122.3$ & $159.2 \pm 261.3$ & 0.053 \\
\hline Total tumor diameter (mm) & $28.6 \pm 16.4$ & $92.5 \pm 30.3$ & $<0.001$ \\
\hline Leukocyte (1000/mm³) & $5.8 \pm 1.1$ & $7.3 \pm 2.8$ & 0.270 \\
\hline Hemoglobin (g/dl) & $12.7 \pm 2.5$ & $11.8 \pm 1.4$ & 0.374 \\
\hline Thrombocyte $\left(1000 / \mathrm{mm}^{3}\right)$ & $140.8 \pm 58.3$ & $155.3 \pm 83.0$ & 0.940 \\
\hline Albumin (g/dl) & $3.3 \pm 0.80$ & $2.9 \pm 0.5$ & 0.193 \\
\hline sTWEAK (pg/ml) & $214.2 \pm 59.6$ & $139.12 \pm 59.8$ & 0.002 \\
\hline
\end{tabular}




\begin{tabular}{|c|c|c|c|}
\hline & & sTWEAK (pg/ml) & $\mathbf{p}$ \\
\hline \multirow[t]{5}{*}{ BCLC stage } & Stage 0 & $212.7 \pm 50.2$ & \\
\hline & Stage A & $185.2 \pm 60.1$ & \\
\hline & Stage B & $165.2 \pm 100.9$ & 0.075 \\
\hline & Stage C & $155.9 \pm 71.5$ & \\
\hline & Stage D & $89.3 \pm 10.3$ & \\
\hline \multirow[t]{3}{*}{ Okuda stage } & Stage A & $181.5 \pm 51.9$ & \\
\hline & Stage B & $170.7 \pm 84.9$ & 0.686 \\
\hline & Stage C & $169.7 \pm 53.7$ & \\
\hline \multirow[t]{2}{*}{ Milan criteria } & Within & $201.1 \pm 56.8$ & 0.025 \\
\hline & Beyond & $150.5 \pm 73.4$ & \\
\hline
\end{tabular}

vival rates were compared using the log-rank test. Statistical computations showed that survival rate was significantly lower in group 1 than group 2 patients $(\log$-rank test, chi-square $=11.75, \mathrm{p}=0.001)$ Kaplan Meier curves are given in Figure 3.

Cox regression analysis, with backward selection, was performed to identify independent predictors of mortality. Among possible risk factors included in the analysis (Age, Child-Pugh stage, total tumor diameter, serum albumin, hemoglobin, Milan criteria and serum sTWEAK concentration), serum sTWEAK concentration (Hazard ratio $=4.325$, \%95 CI: $1.080-17.326, p=0.025)$ and Milan criteria (Hazard ratio $=7.102, \% 95$ CI: 1.286-39.213, $\mathrm{p}=0.039$ ) were identified as independent predictors of mortality.

\section{DISCUSSION}

Technological improvements in imaging instruments, widespread availability of advanced imaging techniques (such as dynamic computerized tomography or magnetic resonance imaging) and routine execution of screening programs have made considerable progress in early and accurate diagnosis of HCC. But therapeutic options are still limited and HCC still constitutes one of the major causes of death among the patients with chronic liver diseases. HCC pathogenesis is multifactorial and complex and better understanding of these contributing factors would facilitate development of novel treatment strategies. We conducted the current study to evaluate serum sTWEAK levels in patients with $\mathrm{HCC}$ and to assess the possible role of sTWEAK in the HCC pathogenesis. The results of the current study showed that, mean serum sTWEAK concentrations were lower in the HCC and cirrhosis groups when compared to healthy controls and low blood levels of sTWEAK were associated with poor survival in HCC patients.

There are only a few studies in the literature investigating serum sTWEAK concentrations in chronic liver diseases. In a previous study, we found that serum sTWEAK levels were lower than healthy controls in non-cirrhotic chronic hepatitis B patients. ${ }^{11}$ That study didn't include cirrhotic group because of its design. In one aspect, current study could be considered to cover the other end of HBV related chronic liver disease spectrum showing that serum sTWEAK concentrations were also decreased in patients with HBV associated cirrhosis and HCC compared to healthy controls. To our knowledge, there is only a single study in the literature evaluating serum sTWEAK levels in patients with cirrhosis. In that study, Fan et al. ${ }^{16}$ have reported that serum sTWEAK levels were significantly higher in acute decompensated cirrhotic patients than controls and serum STWEAK concentrations were found to be positively correlated with new infections, long hospital stays, high 


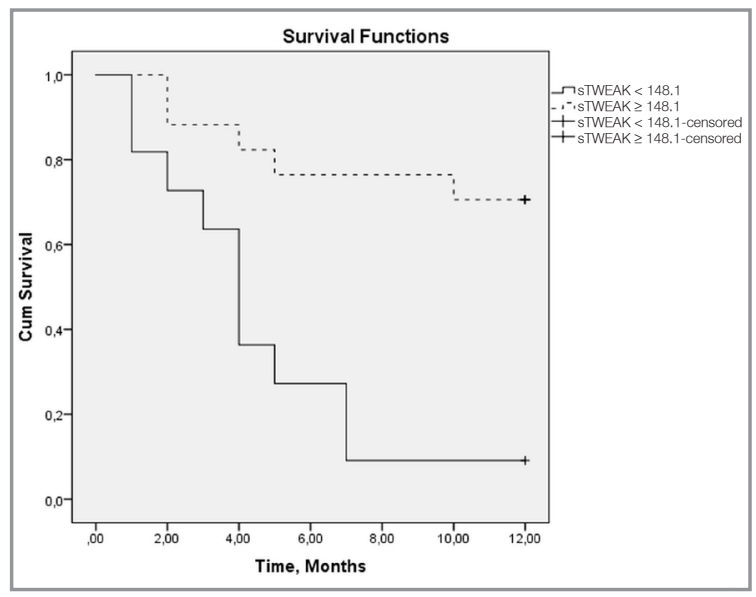

Figure 3. Kaplan-Meier curves according to serum sTWEAK concentrations (sTWEAK $<148.1 \mathrm{pg} / \mathrm{ml}$ and sTWEAK $\geq 148.1$ $\mathrm{pg} / \mathrm{ml})$

medical costs, and high mortality. Our results are not consistent with the findings of that study. One of the possible reasons of this discrepancy would be the differences in the patient selection criteria of the studies. The cirrhotic group in our study consisted of HBV (+) compensated and decompansated cirrhotic patients but as previously mentioned patients with acute complications such as hepatic encephalopathy, spontaneous bacterial peritonitis, esophageal or gastric variceal bleeding and hepatorenal syndrome were excluded because of the possibility that such complications may affect serum sTWEAK levels. On the other hand, in the study of Fun et al. cirrhosis group was heterogeneous including patients with different etiologies and patients with acute decompensation (ascites, hepatic encephalopathy, bacterial infection, variceal bleeding, and hepatorenal syndrome) were also included in the study as a separate group.

To our knowledge there is no other study investigating serum sTWEAK concentrations in HCC patients. But several studies in the literature address the possible role of TWEAK/Fn14 axis in HCC pathogenesis. In a study conducted by Feng et al. ${ }^{17}$ it was shown that Fn14 gene was expressed at low levels in normal liver tissues whereas expression was significantly high in HCC specimens and HCC cell lines. Similarly, Li et al. ${ }^{12}$ have found that both Fn14 expression and Fn14 protein levels were increased in tissue samples of HCC patients. They also reported that Fn14 overexpression was associated with poor overall survival and recurrence in a retrospective cohort of $260 \mathrm{HCC}$ patients. Moreover, inhibition of TWEAK/Fn14 signaling has been shown to inhibit the growth of $\mathrm{HCC}$, both in vitro and in vivo. ${ }^{18}$

At first glance our results seems to be contradictory to previous studies taking into account that serum sTWEAK levels were found to be lower in HCC patients. Because if TWEAK/Fn 14 axis is claimed to contribute to the pathogenesis of HCC, one may expect serum sTWEAK concentrations to increase in HCC patients. But we think that the condition with sTWEAK is a bit more complex. sTWEAK seems to be a decreasing biomarker and there are several studies in the literature reporting decreased serum levels of sTWEAK in various diseases. ${ }^{10}$, ${ }^{19,20}$ In two other studies we have also shown that serum sTWEAK levels were decreased in patients with chronic hepatitis B and non-alcoholic fatty liver diseases. ${ }^{12,21}$ We believe that, a common mechanism would explain the decrease in serum sTWEAK concentration in HCC and cirrhosis patients as well as in other liver diseases; which is the overexpression of Fn14 in diseased tissues. Normally Fn14 expression is very low in healthy tissues and as its name implies Fn14 expression is highly induced in disease conditions including several cancers. ${ }^{5,8,22}$ As previously stated, Fn 14 expression in the liver has also been shown to be upregulated in chronic liver diseases and HCC..$^{12,17,23}$ Therefore, a possible explanation of the decrease in serum STWEAK levels would be the overexpression of Fn14 in cirrhosis and HCC patients resulting in entrapment of circulating sTWEAK molecules by the increased Fn14 receptors. It is also noteworthy to pay attention that, if our hypothesis is true although sTWEAK-Fn14 binding results in a decrease in serum STWEAK concentration, the increased receptor-ligand interaction within the HCC tumor tissues activates TWEAK/Fn14 pathway, possibly contributing to the pathogenesis of HCC.

The results of the current study also showed that serum sTWEAK concentration was related to one year mortality in HCC patients. Our findings in terms of mortality can be summarized as follows; First, mean serum sTWEAK concentration was 
lower in deceased HCC patients than survivors. Secondly, Kaplan-Meier survival estimates and log-rank tests showed that survival rate was significantly lower in patients with serum sTWEAK concentration $<148.1 \mathrm{pg} / \mathrm{ml}$ at the time of initial diagnosis. Finally, serum sTWEAK concentration was found to be independently associated with survival in HCC patients in multivariate analysis. There are studies in the literature reporting the association of low serum sTWEAK concentrations with poor outcomes in other cancers but to our knowledge, this is the first study in the literature reporting the association of serum STWEAK concentration with mortality in HCC patients. ${ }^{24,25}$ There are certain limitations of the current study. First, sample size was relatively small. Secondly, we only measured the serum concentration of sTWEAK. However simultaneous determination of tissue expressions of TWEAK and Fn14 would have better clarified the exact role of TWEAK/Fn14 pathway the HCC pathogenesis. Therefore further studies investigating serum sTWEAK levels and tissue expressions of TWEAK and Fn14 are needed in the era.

In conclusion, serum sTWEAK concentration is decreased in $\mathrm{HCC}$ patients associated with chronic HBV infection. Lower serum STWEAK levels at the time of initial diagnosis are associated with poor survival and higher one-year mortality rates in HCC patients.

\section{ACKNOWLEDGEMENTS:}

Authors thank to Esra Tokman ASIL and Ülkü Kllıç Dertli for their contribution in terms of final English proofreading and grammatical check of the current manuscript.

\section{REFERENCES}

1. Ferlay J, Shin HR, Bray F, et al. Estimates of worldwide burden of cancer in 2008: GLOBOCAN 2008. Int J Cancer 127: 28932917, 2010.

2. Forner A, Llovet JM, Bruix J. Hepatocellular carcinoma. Lancet 379: 1245-1255, 2012.

3. Burkly LC, Michaelson JS, Hahm K, et al. TWEAKing tissue remodeling by a multifunctional cytokine: role of TWEAK/Fn14 pathway in health and disease. Cytokine 40: 1-16, 2007.
4. Lassen UN, Meulendijks D, Siu LL, et al. A phase I monotherapy study of RG7212, a first-in-class monoclonal antibody targeting TWEAK signaling in patients with advanced cancers. Clin Cancer Res 21: 258-266, 2015.

5. Whitsett TG, Cheng E, Inge L, et al. Elevated expression of Fn14 in non-small cell lung cancer correlates with activated EGFR and promotes tumor cell migration and invasion. Am J Pathol 181: 111-120, 2012.

6. Dai L, Gu L, Ding C, et al. TWEAK promotes ovarian cancer cell metastasis via NF-kappa B pathway activation and VEGF expression. Cancer Lett 283: 159-167, 2009.

7. Lin BR, Huang MT, Chen ST, et al. Prognostic significance of TWEAK expression in colorectal cancer and effect of its inhibition on invasion. Ann Surg Oncol 19 Suppl 3: S385-394, 2012.

8. Kwon OH, Park SJ, Kang TW, et al. Elevated fibroblast growth factor-inducible 14 expression promotes gastric cancer growth via nuclear factor-kappa B and is associated with poor patient outcome. Cancer Lett 314: 73-81, 2012.

9. Yin X, Luistro L, Zhong H, et al. RG7212 anti-TWEAK mAb inhibits tumor growth through inhibition of tumor cell proliferation and survival signaling and by enhancing the host antitumor immune response Clin Cancer Res 19: 5686-5698, 2013.

10. Lozano-Bartolomé J, Llauradó G, Rodriguez MM, et al. Reduced circulating levels of STWEAK are associated with NAFLD and may affect hepatocyte triglyceride accumulation. Int J Obes (Lond) 40: 1337-1345.

11. Asil M, Dertli R. Serum soluble TWEAK levels are decreased in treatment naive noncirrhotic chronic hepatitis B patients. Medicine (Baltimore) 95: e4763, 2016.

12. Li N, Hu WJ, Shi J, et al. Roles of fibroblast growth factorinducible 14 in hepatocellular carcinoma. Asian Pac J Cancer Prev 14: 3509-3514, 2013.

13. Okuda $\mathrm{K}$, Ohtsuki T, Obata H, et al. Natural history of hepatocellular carcinoma and prognosis in relation to treatment. Study of 850 patients. Cancer 56: 918-928, 1985.

14. Llovet JM, Brú C, Bruix J. Prognosis of hepatocellular carcinoma: the BCLC staging classification. Semin Liver Dis 19: 329-338, 1999.

15. Mazzaferro V1, Regalia E, Doci R, et al. Liver transplantation for the treatment of small hepatocellular carcinomas in patients with cirrhosis. N Engl J Med 334: 693-699, 1996.

16. Fan WC, Huang CC, Yang YY, et al. Serum pentraxin-3 and tumor necrosis factor-like weak inducer of apoptosis (TWEAK) predict severity of infections in acute decompensated cirrhotic patients. J Microbiol Immunol Infect 2016, doi:10.1016/j. jmii.2015.12.006.

17. Feng SL, Guo Y, Factor VM, et al. The Fn14 immediate-early response gene is induced during liver regeneration and highly expressed in both human and murine hepatocellular carcinomas. Am J Pathol 156: 1253-1261, 2000. 
18. Aronin A, Amsili S, Prigozhina TB, et al. Fn14•TRAlL effectively inhibits hepatocellular carcinoma growth. PLoS One 8: e77050, 2013.

19. Turkmen K, Tonbul HZ, Erdur FM, et al. Soluble TWEAK independently predicts atherosclerosis in renal transplant patients. BMC Nephrol 14: 144, 2013.

20. Beltrán LM, Muñoz Hernández R, de Pablo Bernal RS, et al. Reduced STWEAK and increased SCD163 levels in HIV-infected patients: modulation by antiretroviral treatment, HIV replication and HCV co-infection. PLoS One 9: e90541, 2014.

21. Asil M, Dertli R, Biyik M, et al. Non-alkolik steatohepatit, basit karaciger yaglanmasi hastalari ve saglikli kontrollerde serum soluble tumor necrosis factor-like weak inducer of apoptosis (sTWEAK) düzeyleri. 33. National Gastroenterology Week (33. Ulusal Gastroenteroloji Haftasi), Antalya, November 22-27, 2016: S-010.

22. Burkly LC, Michaelson JS, Zheng TS. TWEAK/Fn14 pathway: an immunological switch for shaping tissue responses. Immunol Rev 244: 99-114, 2011.

23. Jakubowski $A$, Ambrose $\mathrm{C}$, Parr $\mathrm{M}$, et al. TWEAK induces liver progenitor cell proliferation. J Clin Invest 115: 2330-2340, 2005.

24. Avilés-Jurado FX, Terra X, Gómez D, et al. Low blood levels of STWEAK are related to locoregional failure in head and neck cancer. Eur Arch Otorhinolaryngol 272: 1733-1741, 2015.

25. Terra X, Gómez D, García-Lorenzo J, et al. External validation of STWEAK as a prognostic noninvasive biomarker for head and neck squamous cell carcinoma. Head Neck 38 Suppl 1: E1358-63, 2016.

\section{Correspondence:}

Dr. Mehmet ASIL

Necmettin Erbakan Üniversitesi, Meram Tip Fakültesi

Gastroenteroloji Klinigi

42090, Meram

KONYA / TURKEY

Tel: (+90-332) 2236587

Fax: (+90-332) 3237120

e-mail: drmehmetasil@yahoo.com.tr 